DOI: 10.17277/voprosy.2015.03.pp.162-166

\title{
SOME PECULIARITIES OF INCLUSIVE EDUCATION IN KAZAKHSTAN*
}

\author{
N. V. Denivarova, M. K. Abdresheva \\ Buketov Karaganda State University, Republic of Kazakhstan \\ Reviewed by Doctor of Pedagogic Sciences, \\ Professor R. P. Milrood
}

Keywords: children with learning disabilities; inclusive education; needs; State Program of Education Development; teaching; upbringing.

\begin{abstract}
This article considers the possibility of involving schoolchildren with learning disabilities in educational process and the necessity of securing favorable environment and support for children with learning disabilities in accordance with the Law "On Education of the Republic of Kazakhstan" and State Program of Education Development in the Republic of Kazakhstan for $2011-2020$.
\end{abstract}

Nowadays much attention is paid to the problem of inclusive education. Inclusive education of children with learning disabilities is a new strategic direction of educational policy of the Republic of Kazakhstan, significantly addressing fundamental education. It implies maximum possible involvement of children with special needs in common general education institutions and determines the educational culture dynamics in many countries of the world. A number of European Union countries have already made drastic structural alterations that resulted in the abolition of special schools (Sweden, Denmark, Italy, Australia, USA, etc.) [1]. Today, children with learning disabilities study in "the least restrictive environment", in other words, they study together with peers in general education institutions.

The goal of the development strategy in Kazakhstan up to 2030 related to the educational system is "to provide the development of the national educational model and its integration with international educational environment" [2]. The priority of national program "Education" $(2000-2005)$ was to create conditions for efficient development of national educational model, providing access to qualitative education [2]. The implementation of this program involves the transfer from the principle of "education for life" to the

Дениварова Надежда Валерьевна - магистр филологии, старший преподаватель кафедры английского языка и лингводидактики, e-mail: romashkababy1@mail.ru; Абдрешева Мадина Каббасовна - студентка, Карагандинский государственный университет имени академика Е. А. Букетова, Республика Казахстан. 
principle of "lifelong education for everyone", affordability and continuity of all educational levels, comprehensive, qualitative, competitive result-oriented education.

The development of the system of inclusive education is one of the priority directions of the national program of education in the Republic of Kazakhstan for 2011-2020. The rights of children with limited abilities to have equal rights for quality education are consolidated by the legislation of the Republic of Kazakhstan. In the republic there are 138513 children with limited abilities aged to 18 years that makes $2.8 \%$ of the total number of the children's population, including children of school age - 93740 children and preschool age -44773 . The government pays a great attention to education of children with mental retardation. Special education for the children with disabilities is introduced in 37 special kindergartens and 101 special needs schools, 240 special groups and 1098 special classrooms in comprehensive schools. Approximately ten thousand children are involved in home teaching within the individual program.

In 2007, 6.6 thousand students were involved in inclusive education in 241 schools within the country. Depending on the extent of disorders in psychophysical development and cognitive capabilities, students are trained using special educational programs and textbooks designed for different levels of cognitive development of students with disabilities. In the republic, the work on elaboration, publication of Kazakhstani textbooks and learning resources of special correctional educational organizations in 8 major kinds and types has been carried out since 2004; at the present time there are 56 psychologicalmedical and pedagogical consulting offices that render medical and psychological-pedagogical support to the population in revealing, diagnosing and consulting children with mental retardation.

Correctional and pedagogical support is provided in 156 inclusive education centers for preschool age children from early years; there are 123 psychological and pedagogical correction centers, and 345 speech therapy units. However, organization of complex diagnostics of developmental disorders and the system of early correctional and pedagogical support enables only a third of all children with disabilities to be engaged in the educational process. Equal access to education for preschool children with limited developmental abilities is not fully provided. The scope of children with disabilities involved in the special study programs is only 41.4 percent. The multimedia equipment is available to 35 to 60 percent in special needs organizations. Unfortunately, equal rights of children with disabilities to receive quality education are not satisfied in full; weak implementation of inclusive education is caused by insufficient awareness of population and poor use of media to promote the ideas of inclusive education

Inclusive education is based on the following principles:

1) the value of a person doesn't depend on his (her) abilities and achievements;

2) every person is able to feel and to think;

3 ) every person has the right to communicate and to be heard;

4) all people need each other;

5) education can be implemented only in the context of real relations;

УНИВЕРСИТЕТ им. В.И. ВЕРНАДСКОГО. №3(57). 2015. 
6) all people need support and friendship of their peers;

7) for each student progress means reaching for success, not failure;

8) diversity intensifies all aspects of human life.

The system of inclusive education involves primary, secondary and higher educational institutions. The set of measures assumes both technical equipping of educational institutions and development of the curriculum by educators for disabled people and interaction with them. There is also an obvious necessity in special programs developed to facilitate the adaptation of children with physical disabilities at educational institutions.

The educational system of Kazakhstan is still in the process of democratization. This is the stage of strengthening humanistic approaches to upbringing, development and education of the future generation. This involves creating conditions favorable for creative development, self-education of all children including those with disabilities. Education as a process of knowledge and skill acquisition is an integral part of social and psychological adaptation and integration of disabled children in the society. It is aimed at providing them with the access to knowledge and cultural and historic heritage of the humanity. The educational environment prepares these children for professional activity and stimulates their personal development. Inclusive education is also considered to be the best form of establishing optimal interactions with surrounding people as coeducation itself allows improving the quality of everyday communications among children that have vital functional limitations.

The Government of the Republic of Kazakhstan introduced "The National Program of Development of Education in the Republic of Kazakhstan for $2011-2020$ " with the development of inclusive education as one of the priority goals. The program includes measures of creating a legal framework for all children and also children with developmental disabilities to be involved in the general education area [2].

The process of implementation of inclusive education in Kazakhstan is based on sociological and scientific studies that were made in the last decade by the experts of the National Research Centre for Special Education. This project studied international experience and views on inclusive education of various social groups. Also, the analysis of statistical data on children with special needs across the regions of the country was made in four areas: health, education, social security, internal affairs. It was decided to use a "spontaneous" approach to inclusion of children with disabilities in mass pre-school and school organizations. Such experience has a good influence on different regions of our country during the course of these studies and reviews.

An inclusive school considers every student as an important part of a group which gives them a sense of confidence that can be the reason for the children to be responsive and kind. Disabled students are supported by their classmates. Nowadays there are a lot of schools that use an inclusive education system, but there are still many problems. Here are some of them:

- problems in the structure of educational institutions;

- in most cases disabled students are considered to be uneducable;

- the majority of school teachers and principals do not have proper education in the area of teaching disabled students, so they are not ready to involve disabled students into education process; 
- disabled students' parents do not know how to defend their children's rights to education.

- educational establishments in most cases do not consider the abilities of every child. The reasons for this are overcrowded classes, and teachers just have no time to apply an individual approach to every student $[3,4]$.

To make the concept of inclusive education nationwide it is necessary to consider the experience of foreign countries, which can be carried out by specialists as most of current teachers are not able to change their approach to educational system. Inclusive education is based on the idea that all the children should be treated in the same way, but disabled children should get special attention. About $15 \%$ of students are expelled because of system's inability to meet their needs. We should understand that it is the system to be blamed, not the children. Inclusive approach will give them a chance for a better life. Common education system is a process of general education, which means that every child is able to get knowledge. The main point of inclusive education is developing a methodology where every child is an individual that has different needs. And if teaching became more effective due to changes that introduce inclusive education it would have positive effect on all the students [3].

Inclusive education requires training of teachers who can work with disabled children. In this regard it is necessary is to improve university teacher training. Didactic foundations of correctional and pedagogical training are components of professional educational system containing a unified bunch of aims, objectives, content and technologies of its implementation. At the same time, there are some problems of teacher training: didactic bases of training are still not disclosed, theoretical model is not developed, target program and process components of training are not defined, etc. The purpose of correctional and pedagogical training of elementary school teachers should cover professional knowledge and skills, and also the formation of a high-skilled personality who possesses the integrated psychological-pedagogical thinking. A specialist, who works with disabled children should be trained both in cognitive and personal aspect to implement humanistic principles in the course of interaction with children, should be able to rely on personal growth of a child, to take into account individual peculiarities of his mental activity, to create positive perspectives of his development, to organize an educational environment that enables to identify and to realize the creative potential of a child.

For the purpose it is necessary to develop a program-targeted component of students' training in mental retardation classrooms. Training courses should include "Correctional Pedagogy", "Integrated Correctional and Developing Education of Children with Mental Retardation in Elementary School Classrooms" of students training in the research area at the final stage of their training. The structure of classes consists of three interconnected components:

- discussion and analysis of theoretical;

- pedagogical training;

- pedagogical practice.

Today, teachers, speech therapists, educational psychologists, speech pathologists, physical therapy instructors, educators and tutors are involved in the development of an inclusive educational environment. Their joint work is expected to result in the development of child's abilities, creation of social 
relations system, satisfaction of special needs, creation of a comprehensive support system, a functional approach to teaching and treatment, participation in public activities, etc.

Inclusive education is aimed at developing new methods of teaching that will meet the needs of different students. And if education becomes more effective owing to changes that inclusive education adopts, all students will benefit from it.

\section{References}

1. Stubbs, S. Inclusive Education Where there are few resources / S. Stubbs. Oslo : Atlas-alliance, 2002. - $66 \mathrm{c}$.

2. Национальная программа развития системы образования в Казахстане на 2011 - 2020 // Казахстанская правда. - 2010. - 14 дек.

3. Митчелл, Д. Эффективные педагогические технологии специального инклюзивного образования / Д. Митчелл. - М. : Перспектива, 2011. - 283 р.

4. Назарова, Н. М. Специальная педагогика / Н. М. Назарова. - М. : Академия, 2000. $-232 \mathrm{c}$.

\section{References}

1 Stubbs. S. Inclusive Education Where there are few resources, Oslo: AtlasAlliance, 2002, $66 \mathrm{p}$.

2. President of the Republic of Kazakhstan, State programme of Education development in the Republic of Kazakhstan for 2011 - 2020, Astana, 2010.

3. Mitchell D. Effektivnye pedagogicheskie tekhnologii spetsial'nogo inklyuzivnogo obrazovaniya (Effective pedagogical technologies of special inclusive education), Moscow: Perspektiva, 2011, 283 p.

4. Nazarova N.M. Spetsial'naya pedagogika (Special teacher training), Moscow: Akademiya, 2000, $232 \mathrm{p}$.

\section{Некоторые особенности инклюзивного образования в Казахстане}

\section{Н. В. Дениварова, М. К. Абдрешева}

Карагандинский государственный университет имени академика Е. А. Букетова, Республика Казахстан

Ключевые слова: воспитание; государственная программа развития системы образования; дети с ограниченными возможностями; инклюзивное образование; обучение; образование.

Аннотация: Раскрыты цели, задачи, принципы и основные направления развития инклюзивного образования в Казахстане и обоснована необходимость обеспечения равных прав на получение качественного образования детьми с ограниченными возможностями в соответствии с государственной программой развития образования в Казахстане на $2011-2020$ гг.

(C) Н. В. Дениварова, М. К. Абдрешева, 2015 